\title{
Capitalism, culture, agency: dependency versus postcolonial theory
}

\section{ILAN KAPOOR}

ABSTRACT This article reads dependency alongside and against postcolonial theory in an attempt to reinvigorate and re-validate some of the insights of the former, while at the same time supporting the latter's current ascendancy in the field of Third World politics. It is argued that although dependency and postcolonial theory share some common territory-a suspicion of Western liberal modernity, a critical-historical analysis-they tend to have irreconcilable differences that show up their respective strengths and vulnerabilities. Dependency chooses a structuralist and socioeconomic perspective, seeing imperialism and development as tied to the unfolding of capitalism, whereas postcolonial theory favours a post-structuralist and cultural perspective, linking imperialism and agency to discourse and the politics of representation. The article stages a mutual critique of them, based on the work of Frank, Cardoso \& Faletto, Said, Spivak and Bhabha.

The dependency school seems to have lost favour among current scholars of social science and Third World politics, whilst postcolonial theory-in spite of, or perhaps because of, growing out of literary studies - appears to be on the rise. This trend is at least partly the result of the fresh and exciting perspective that postcolonial theory brings relative to (or retrospective to) dependency, much as the latter did in the mid-1960s and early 1970s in relation to 'modernisation'. But the contemporaneity and novelty of the one need not blind us to the continuing importance of the other. In fact, I want to suggest that reading dependency alongside and against postcolonial theory can help reinvigorate and re-validate some of the insights of the former, while at the same time supporting the latter's ascendancy.

Dependency and postcolonial theory cover some similar territory and share important common concerns - a suspicion of Western liberal modernity, a historical-global analysis, and a critical politics. Yet at the same time, as Christine Sylvester points out, 'One field [development studies, of which dependency is part] begins where the other refuses to look' (1999: 704). Dependency chooses a structuralist and socioeconomic perspective, seeing imperialism as tied to the unfolding of capitalism, whereas postcolonial theory favours a post- 
structuralist and cultural perspective, linking imperialism and agency to discourse and the politics of representation. Dependency's politics is premised on state and class control of capitalist development; postcolonial theory's on the subaltern subversion of orientalist modes of representation.

I shall not attempt, in this article, to reconcile or synthesise these differences. Rather, believing (and showing) them to be irreducible, I shall stage a mutual critique of the two by bringing their tensions-economy and capitalism versus culture and representation, structuralist versus post-structuralist politics - to productive crisis. Reading one against the other will help draw out the strengths and persuasiveness, but equally the limits, vulnerabilities and blind spots, of both. Accordingly, after outlining the main arguments of, and similarities between, dependency and postcolonial theory, the article will stage a mutual critique of them. The fault lines of this mutual critique will be drawn principally around the status, if any, each gives to the issues of capitalism, culture and agency.

Some brief programme notes on the characters in this staged mutual critique: I shall rely mainly, although not exclusively, on a close reading of the work of Frank and Cardoso \& Faletto to treat dependency, and that of Said, Spivak and Bhabha to treat postcolonial theory. While not representative of the entirety of their respective schools of thought, the writing of these theorists provides a sense of the variety, refinement and even divergences within each school. Moreover, I shall 'stage' the mutual critique more in one direction than in the other: postcolonial theorists have commented on dependency and Marxist theory (albeit mostly on the latter); while the dependentistas, unable to enjoy this chronological advantage, cannot have (and have not) commented on postcolonial theory. I will attempt to redress this disadvantage by leaning on contemporary critics of postcolonial theory (eg Ahmad, Dirlik, O'Hanlon \& Washbrook, Parry), whose mainly Marxist arguments conform at least in spirit to those of the dependentistas, ${ }^{1}$ and who will serve, so-to-speak, as understudies .

\section{Dependency}

André Gunder Frank's insights derive primarily from his critique of modernisation's 'dual society' thesis. This thesis holds that the 'modern' and 'traditional' sectors of developing societies are independent. The former sector is modern because of its exposure to the outside capitalist world. The latter is 'underdeveloped' because it has lacked such exposure; but it can be modernised through the diffusion of 'capital, institutions, values' (Frank, 1969: 4). Based primarily on research on Chile and Brazil $(1967,1969)$, Frank argues that, on the contrary, 'underdevelopment is not due to the survival of archaic institutions and the existence of capital shortage ... [but] is generated by the very same historical process which also [generates] economic development: the development of capitalism itself' (1969: 9). Far from being separate, the modern and traditional sectors and areas are 'fully ... integrated parts of the imperialist system' (1969: 221). Latin America may have been 'undeveloped' in pre-colonial times, but it is 'underdeveloped' as soon as capitalism arrives on its shores. And it is this selfsame underdevelopment that makes possible Europe's modernisation (1969: 4). 
Frank concludes that 'Economic development and underdevelopment are the opposite faces of the same coin' (1967: 9).

For Frank, imperialism is primarily about the appropriation of 'economic surplus', a process that begins when Brazil and Chile are colonised and that ends up integrating even the most isolated areas into the global capitalist system: 'a whole chain of constellation s of metropoles and satellites [or "peripheries"] relates all parts of the whole system from its metropolitan center in Europe or the United States to the farthest outpost in the Latin American countryside' (1969: 6; see also 226; 1967: 6-7, 10,16). National development in the colonial and postcolonial $^{2}$ periphery is thus severely constrained: the periphery is 'condemned to underdevelopment' (1967: 11).

Frank has little faith in the national bourgeoisie playing a progressive role even after political independence, believing it to be nothing more than a collaborator in imperialism. He writes that the 'national bourgeoisie, where it can be said to exist, and indeed the entire national metropolis and capitalist system on which it thrives, are necessarily so inextricably linked into the imperialist system and the exploitative metropolis-periphery relationship it imposes on them that it cannot possibly escape from and can only extend and deepen the resulting underdevelopment' (1969: 228-229; see also 1967: xv, 118; 1972). The only way forward, according to him, is socialism, to be arrived at through revolutionary 'class struggle' and even 'guerrilla warfare' (1969: 371-372, 402).

Like Frank, Fernando Henrique Cardoso and Enzo Faletto adopt a 'historical' and 'structural' approach to dependency, viewing capitalism as a 'world system' (1979: x, xxi, 23). But their approach differs from Frank's in being 'dialectical'. They analyse dependency as a complex outcome of global capitalist relations: 'We do not see dependency and imperialism as external and internal sides of a single coin, with the internal aspects reduced to the condition of "epiphenomenal"' (1979: xv; see also ix, 22, 173). Based on a number of Latin American case studies, they specify the varied and complex ways in which imperialism and capitalism manifest themselves, concluding that dependency is the result not of the "abstract "logic of capital accumulation" but ... of particular relationships and struggles between social classes and groups at the international as well as at the local level' (1979: xvii; see also xiii, 173). This conclusion leads them to resist a 'theory of dependent capitalism' in favour of specific 'situation $\mathrm{s}$ of dependency' (1979: xxiii).

Unlike Frank, who pays scant attention to social analysis, Cardoso and Faletto focus their study on how local social groups and practices reproduce and/or resist imperialism (in the post-colonial period). ${ }^{3}$ They delineate two main dependency situations, one in which there is a relatively strong local state that allows for more national control of development, the other, an 'enclave situation', in which foreign interests dominate, thereby allowing for less national control. For Cardoso and Faletto, the type of local dependency is dictated by the specific nature of alliances among and between local and foreign classes, groups and ideologies (labour, peasantry, national or collaborating bourgeoisie, state bureaucracy, landed/traditional oligarchies, the army, ethnic groups, nationalism, populism, multinational corporations, international financial systems, foreign states, etc) (1979: xvi-xx, 17-18, 27, 174). For example, at times, the ruling 
bourgeoisie may ally itself with foreign multinational corporate interests, while at others it may seek an alliance with local classes and groups to better insulate itself from these foreign corporate interests. Of note here is Cardoso and Faletto's articulation of what they call a 'new dependency', ushered in by the rise of mainly US multinational corporate power in Latin America after the second world war (1979: xvii, xxii).

Cardoso and Faletto's dialectical approach suggests various degrees of dependency, so that, given the appropriate sociopolitical alignments, dependent relations can generate some growth and do not necessarily have to induce underdevelopment: "in spite of structural "determination," there is room for alternatives in history' (1979: xi). Cardoso thus speaks of "associated-dependent development' (1973), and appears to be distinguishing himself from Frank when he writes that 'it is possible to expect development and dependency' (1972: 94, emphasis in the original). But despite the possibility of some growth, he and Faletto end up in agreement with Frank when they advocate that Latin America's dependency ties ultimately need to be broken by constructing 'paths toward socialism' (1979: xxiv; see also 19). What such paths entail remains vague, although other dependentistas such as Celso Furtado (1970) suggest a move to more autonomous development through regional (Latin American) co-operation.

\section{Postcolonial theory}

In contrast to dependency, which relies on social science methodology and 'field' research, postcolonial theory emerges out of literary studies, disclosing its arguments based primarily (although not exclusively) on literary sources. Edward Said's work (1995-originally published 1978, 1993) builds on an analysis of Western novels (eg Austen, Conrad, Chateaubriand, de Nerval, Flaubert), travel and anthropological writing (Burton, de Sacy, Renan), opera (Verdi) and media (mainly in the USA) to link Western imperialism with Western culture. This linkage produces what Said calls 'orientalism'. Orientalism is the systematic 'body of theory and practice' that constructs or represents the Orient (1995: 6; see also 1993: xxiii; 1985: 248). By 'theory' Said means the Western imperial episteme-the West's intellectual and cultural production, including research, writing, ideas, arguments, images; and by 'practice' he denotes the accompanying sociocultural institutions and structures-the colonial administration, universities, museums, media, etc (1995: 3, 5, 332).

While Said distinguishes between British and French imperial orientalism, as well as between colonial and post-colonial Western orientalism, he argues that there is general continuity in the way West and East are depicted (1995: 3-4, 201ff). Westerners tend to be characterised as 'rational, peaceful, liberal, logical ... without natural suspicion' (1995: 49) and easterners as irrational, degenerate, primitive, mystical, suspicious, sexually depraved and so on (1993: xi; 1995: 49, $172,187-188,190)$. What is important for him is that these representations are not neutral; drawing on Foucauldian discourse theory, he shows how they are laden with a 'will to power', a will 'to control, manipulate, even to incorporate, what is a manifestly different ... world' (1995: 12). In this sense, orientalism is the 'enormously systematic discipline by which European culture [has been] able 
to manage-and even produce-the Orient politically, sociologically, militarily, ideologically, scientifically, and imaginatively during the post-Enlightenment period' (1995: 3).

Although Said does later recognise it (1993: xii), 'orientalism' tends to be an overly unifying and monolithic concept, at least as it is portrayed in Orientalism: it depicts colonial discourse as all-powerful and the colonial subject as its mere effect. This tendency is evident in the following statement: 'because of Orientalism, the Orient was not (and is not) a free subject of thought or action' (1995: 3). ${ }^{5}$ And it is partly in response to this tendency that Gayatri Chakravorty Spivak and Homi Bhabha make their respective interventions. While accepting the general idea of orientalism, which Spivak indicates as the "worlding" of what is today called "the Third World"' (1985a: 247), both theorists show it to be ruptured and hybrid. Bhabha suggests that Said himself hints at, but leaves undeveloped, this idea in Orientalism (1994: 73; Young, 1990: 141-142). In fact, Bhabha makes 'hybridity' the keystone of his subsequent elaborations.

Hybridity describes the way in which colonial and imperial discourse is inherently unstable, 'split' in its 'enunciation', so that 'in the very practice of domination the language of the master becomes hybrid' (Bhabha, 1994: 33). Bhabha illustrates this instability through an analysis of the 'colonial stereotype', which he considers an instance of the deployment of imperial authority. Applying a post-structuralist (in particular, a Lacanian ${ }^{6}$ psychoanalytic) lens to various colonial texts, Bhabha shows how these stereotypes - the 'noble savage', the 'wily oriental' - are meant to be accepted as 'fixed' and 'natural'; yet they are endlessly and anxiously repeated and reconfirmed by the coloniser. Often the stereotypes are also contradictory: the colonial subject, Bhabha writes, is 'savage (cannibal) and yet the most obedient and dignified of servants (the bearer of food); he is the embodiment of rampant sexuality and yet innocent as a child; he is mystical, primitive, simple-minded and yet the most worldly and accomplished liar' (1994: 82; see also 66, 85ff, 111). Such repetition, such 'double inscription', for Bhabha, betrays the slipperiness and ambivalence of colonial discourse and authority (1994: 108).

Discursive instability has two important implications. First, it makes for agency. While critical of imperialism's discursive violence, Spivak speaks of an 'enabling violence' (1996: 19; see also 1988a: 198) and of the persistent transformation of 'conditions of impossibility into possibility' (1988a: 201). Similarly, Bhabha sees discourse as both 'incitement and interdiction' (1994: 72), its doubleness empowering: 'The ambivalence at the source of traditional discourses on authority enables a form of subversion, founded on the undecidability that turns the discursive conditions of dominance into the grounds of intervention' (1994: 112).

Bhabha conveys this subversive intervention by way of a number of incidents,? possibly the most notable of which is found in 'Signs Taken for Wonders' (1994: 102ff). Here, Bhabha cites an Indian catechist's own record of how he tries to convert a group of villagers outside Delhi in 1817. But the villagers resist on the basis of their vegetarianism, arguing that they will accept the sacrament only if they can be convinced that the evangelical utterances do not come from the mouths of meat-eaters. Bhabha interprets the incident as a sign of 'spectacular 
resistance' (1994: 121), ${ }^{8}$ writing that 'When the natives demand an Indianized Gospel [or, in effect, a 'vegetarian Bible'!], they are using the powers of hybridity to resist baptism and to put the project of conversion in an impossible position' (1994: 118). He goes on to explain that the episode is not just 'an exchange between a muscular colonial Christianity that was keen to convert and an indigenous tradition that resisted conversion' but a 'colonial antagonism' that produced a 'supplementary' discourse as a site of 'resistance and negotiation' (1995b: 114).

Bhabha provides contemporary illustrations of agency as well. He singles out, for example, the British group, Women Against Fundamentalism, for using the Rushdie affair, not to endorse or defend either Western liberalism or Islamic conservatism, but to draw attention to women's issues (household inequality, education, prostitution), thereby 'reconjugating, recontextualizing, translating the event into the politics of communities and public institutions' (1995b: 114). Bhabha's point, in these and other coloniser-colonised and migrant-metropolitan encounters, is to demonstrate that agency is a kind of cultural and 'psychological guerrilla warfare' (Moore-Gilbert, 1997: 130). It involves estranging, contaminating or misreading the master discourse, at times imposing suppressed knowledge and at others making unanticipated, slight alterations, with the overall effect of denying or subverting dominant authority.

It should be noted that such agency is emergent only from within the master discourse, a situation that Spivak describes as saying an "impossible "no" to a structure, which one critiques, yet inhabits intimately' (1990b: 228). This means that there is unavoidable collusion and complicity between the coloniser and colonised (Spivak, 1985b: 9; 1988a: 180). Not surprisingly, Bhabha repeatedly refers to subaltern agency as a form of 'negotiation' (1994: 25, 38, 185, 191). It also means that the agent cannot harken back to pre-colonial, pre-orientalist discourse in search of an 'authentic' identity or out of 'nostalgia for lost origins' (Spivak, 1988b: 291). According to both theorists, colonial discourse has forever marked colonised and ex-colonised societies (and for that matter colonial and ex-colonial powers), so that it is impossible to recuperate any identity uncontaminated by it. They thus warn of the dangers of direct opposition to dominant power, arguing that the result is often reverse orientalism and racism or substitution of one power for another. Referring to Spivak, Bart Moore-Gilbert explains that "directly counter-hegemonic discourse is more liable to cancellation or even reappropriation by the dominant than a "tangential", or "wild", guerrilla mode of engagement. For this reason, too, she advocates the modes of "negotiation" and "critique", which unsettle the dominant from within' (1997: 85).

The second (and related) implication of the instability and 'doubleness' of discourse is that it enables the retrieval and recognition of difference. The object of postcolonial concern here is orientalist binary categorisation (eg master-slave, coloniser-colonised, civilised-uncivilised, white-black), into which the 'other' is invariably incorporated. Postcolonialism seeks to preserve heterogeneity and to criticise its disparagement or transcendance by any master discourse. Said likens this task to 'counterpoint' in baroque music, where several music lines hold together without one dominating (1993: 51). Bhabha, for his part, coins 'third space' (1994: 37) as an in-between, incommensurable location in which minority 
or 'supplementary' discourses intervene to preserve their peculiarity. He also speaks of 'time-lag' as a way of validating different temporalities and 'reconstructing other kinds of histories' (1995a: 87). Here, metropolitan time (or Western 'modernity') is not allowed to be used as a standard or measuring rod for non-Western time(s) or 'traditions'.

One of the principal ways in which difference is valorised is by focusing on the marginalised. This is evident in Bhabha's above-noted work on the agency of the colonised and the migrant. But it is Spivak who may be said to emphasise it most. As a member of the Subaltern Group (1988a: 197ff.), whose aim is to write history 'from below', Spivak declares her interest in 'subsistence farmers, unorganized peasant labour, the tribals and communities of zero workers on the street or in the countryside' (1988b: 288). But among these, she pays particular attention to the 'disenfranchised woman' whom she argues is the figure 'most consistently exiled from episteme' (1990a: 102-103; see also 1985a, 1988b, 1993: 177ff).

Paradoxically, while trying to retrieve the voice of the 'gendered subaltern', Spivak admits her failure. In perhaps her most famous text, 'Can the subaltern speak?' (1988b), she concludes that the 19th-century sati (the widowed woman who immolates herself or is immolated) cannot speak because she is never empowered to speak. Her voice is always mediated and appropriated by others (the colonial administrator, patriarchal institutions, the academic intellectual, etc): 'Between patriarchy and imperialism, subject-constitution and objectformation, the figure of the woman disappears' (1988b: 306). Spivak concludes that, nonetheless, the role of the postcolonial critic is to record this silence or disappearance so as to valorise the 'difference' revealed by the disenfranchised woman and to criticise the domination of imperial and patriarchal discourses.

\section{A postcolonial critique of dependency}

Before I stage the mutual critique-the postcolonial critique of dependency and the dependentista critique of postcolonial theory-the common territory between the two must be briefly noted. For, in many ways, this common territory forms a basis for comparison, but is also divided territory that will enable the mutual critique.

Perhaps more than anything, what brings dependency and postcolonial theory together is their shared commitment precisely to critique. In their own fashion, both are counter-modernist and critical of Western liberalism. And this critique yields a correspondingly shared critical politics, aimed principally at arresting the status quo of liberal modernity. In response to the liberal/modernisation tendency to explain the rest of the world in Euro-North American terms, each attempts to shift the focus to the 'periphery'. As a reaction to the West's tendency to neglect examining its past, each accentuates the study of colonial and imperial history for understating modernity in the Third World and in the West. In this sense, analysing history amounts to analysing the trajectory of hegemonic world systems and structures, endowing both dependency and postcolonial theory with a global outlook.

Yet their critique is shared only up to a point, as it rests primarily on the 
identification of a common foe-liberal modernity. Past this initial meeting of minds, both diverge significantly. Dependency singles out the inequality wrought by global capitalist development as crucial, while postcolonial theory zeroes in on the discursive power wielded by orientalism. This tension-between focusing on 'capitalism' or 'representation', and over how best to fashion a matching politics that is sufficiently critical-is what lies at the heart of the debate.

\section{Dependency's orientalism}

From the postcolonial standpoint, dependency ignores (for the most part) culture and the politics of representation. Frank gives them no place in his analysis, and Cardoso and Faletto, while including ideology (eg nationalism, populism) and sociocultural groups in their dialectical approach, tend to treat these as superstructural or epiphenomenal. That is, culture is a factor, but it is viewed only in relation to the political economy. It matters only to the extent that it helps or hinders dependent development. Thus, they look at it as one element among many, and more precisely as a subordinate element, in their politics. ${ }^{9}$ They do not examine the politics of (and within) culture, and are unaware of the way in which culture frames their own analysis. Indeed, their (and Frank's) neglect of the politics of representation results in ethnocentrism.

From the point of view of the dependentistas, this neglect is unfortunate, given their intention precisely to look at imperialism from the perspective of the periphery (Blomström \& Hettne, 1984: 37); but from the point of view of postcolonial theorists, it is not unexpected, given their argument (noted above) that counter-discourses often reverse or perpetuate orientalist representations. Such is the case with dependency's construction of binary opposites- 'developedunderdeveloped', 'centre-periphery', 'metropole-satellite'-which, although attempting to shift analytical focus to the second term, leave unexamined and untouched the power relationship between the two. The 'centre' continues to be just that-central and dominant-so that the West ends up being consolidated 'as sovereign subject' (Spivak, 1985a: 247). Not surprisingly, many have argued that, despite intentions to the contrary, such a discursive hierarchy contributes to a psychology of perpetual dependence in the 'periphery', habituating colonised and ex-colonised subjects to being peripheralised (Fanon, 1967; see also James, 1997: 207).

Dependency's ethnocentrism pervades its historical analysis as well. As Said states, historicism of the type put forth by dependency 'has meant that one human history uniting humanity either culminated in or was observed from the vantage point of Europe, or the West' (1985: 22). In equating its analysis of history with the analysis of the unequal development of global capitalism, dependency forgets that it is using (as did Marx and Lenin before it) Europe as a universal model. In this sense, it is not just capitalism, but the way capitalism develops in Europe that is 'made to stand for History' (Prakash, 1992: 15). Third World countries thereby become specimens of failed or 'dependent' capitalism, with capitalist economic growth as the 'unquestioned norm' and goal to emulate (Spivak, 1985a: 260; Manzo, 1991: 6; Werbner \& Ranger, 1996: 3; Pieterse \& Parekh, 1995: 2). Even Cardoso and Faletto's dialectical approach does not escape this tendency: for 
all its complexity, their dialectics nonetheless strive towards an autonomous capitalist development (a prerequisite for transcendence to socialism).

The crucial problem from where postcolonial critics stand is that master historical narratives-dialectical or not-ignore, domesticate or transcend difference: 'theories of accumulation on a world scale ... depend ... on a homogenizing and incorporating world historical scheme that [assimilates] nonsynchronous developments, histories, cultures, and peoples to it' (Said, 1985: 22; see also Prakash, 1990; 1992: 8, 13; Werbner \& Ranger, 1996: 4). While not averse to using Marxist or class analysis herself (more on this point later), Spivak is particularly concerned with the way in which totalising and economic narratives tend to be blind to non-economic questions such as gender and race (1985a: 263ff, 265ff). Part of the reason why she and Bhabha devote attention to the subaltern and marginalised is to valorise their difference, or what Bhabha calls their 'struggle for the historical and ethical right to signify' (1995a: 51, emphasis in the original). In this sense, postcolonial theorists attempt a 'catachrestic' strategy of 'displacing, and seizing the apparatus of value-coding' (Spivak, 1990b: 228) so that difference is not allowed to be sublated and the West is relativised, de-ethnocentrised and provincialised (Chakrabarty, 1992). Bhabha's deployment of 'time-lags' and incommensurable temporal dimensions, as pointed out earlier, is precisely a way of denying modernity's linear and teleological time and showing how it is 'staged': 'belatedness functions to critique certain priorities and myths about culture and modernization' (1995a: 58, 87). Stuart Hall summarises it well when he writes:

It is the retrospective re-phrasing of Modernity within the framework of 'globalisation' in all its various ruptural forms and moments ... which is the really distinctive element in a 'post-colonial' periodisation. In this way, the 'post-colonial' marks a critical interruption into that whole grand historiographical narrative which, in liberal historiography and Weberian historical sociology, as much as in the dominant traditions of Western Marxism, gave this global dimension a subordinate presence in a story which could essentially be told from within its European parameters. (1996: 250)

Interestingly, while not identifying postcolonial and postmodern critiques of ethnocentrism as a cause, Frank appears to have modified his stance on this issue of late. In his more recent work, which has shifted to 'world system' analysis, he argues that the global (economic) system has been around for 5000 years, with Europe being its driving force for only a portion of that time. In fact, he argues that 'from a global perspective Asia not Europe held center stage for most of early modern history' (Frank, 1998: xv; see also xxv, 1ff; Frank \& Gills, 1993: 3ff; Frank, 1977). From a postcolonial perspective though, his economistic bias, and his partiality to 'totalising narratives', remain.

\section{Subjection and agency}

As noted above, Spivak and Bhabha see politics as emergent from within the master discourse. Agency and subjection, in this sense, are intimately related: the type and degree of agency is tied to the type and degree of power. This argument 
provides a way of critically assessing dependency's views on power and politics.

Dependency and postcolonial theory concentrate on different configurations of power, the former on the power of imperialism and capitalism, the latter on the power within colonial discourse and orientalism. Yet both agree on the pervasiveness of this power. Frank and Said accentuate the overarching grasp of capitalism and orientalism. And despite their reservations about Said's analysis of orientalism, Spivak and Bhabha concur. In fact, their examination of everyday coloniser-colonised encounters, of what Bhabha (echoing Foucault) calls the 'microtechnics of [colonial] power' (1994: 116), demonstrates the extent of penetration of colonial discourse. In this regard, Spivak, while insistent on examining subaltern subjection, also reminds us that on the other side lie colonial agents, who 'are not only great names ... but also small unimportant folk ... as well as policymakers' (1985a: 254).

But unlike the postcolonial theorists, who see power as pervasive yet fractured, Frank constructs power as homogeneous and totalising. He argues, as mentioned earlier, that Latin America is incorporated into the international division of labour as soon as it is colonised. Moreover, for him, capitalism 'fully penetrat[es]' and 'fully integrate[s]' the satellite (1967: xi-xii).${ }^{10} \mathrm{It}$ is not surprising, then, that he advances no possibility of resistance to imperialism (at least under colonial rule), and in fact speaks of the periphery being 'condemned to underdevelopment'. For him, the only way to oppose power conceived as all-pervasive-and-withoutremainder is to obliterate it by means of an equally totalising and monolithic power-violent revolution. From the postcolonial standpoint, these arguments are deeply problematic. For, once again, they overlook that the replacement of one totalising power by another strongly risks the continuation of domination and violence. Moreover, from the perspective of the periphery that Frank is purportedly concerned about, the arguments are disempowering: the Third World is portrayed as a passive bystander in the imperial and capitalist game, with no will or ken to resist it.

It should be noted here that Frank's winner-takes-all view of power resembles Said's (at least the Said of Orientalism). However, Said strays considerably from Frank in never espousing violence or 'revolution'; as suggested earlier, in his later writings he rejoins Spivak and Bhabha's arguments on the pervasiveness yet hybridity of imperial and orientalist power.

In contrast to Frank's concept, Cardoso and Faletto's structural, yet dialectical and differentiated, notion of power shares much with the postcolonial understanding of it as discursive yet split. Just as agency, for Bhabha and Spivak, springs from within (and despite) discursive subjection, politics for Cardoso and Faletto is emergent and possible within the capitalist frame: development can happen in spite of dependence. But, once again, there is a crucial difference: whereas for the former agency is always possible (it derives from the ever-hybrid character of discourse), for the latter (including Frank) it is possible only in the wake of political independence from colonialism.

From the postcolonial perspective, dependency's thinking on this question contains several problematic assumptions. Dependency's agent or subject of change appears only after the coloniser has relinquished political power. The postcolonial critics beg to differ. Not only are Spivak and Bhabha critical of the 
orientalising and incapacitating tendencies of this position, they also show how colonial discourse's production of subjects is witnessed by numerous acts of subversive resistance on the part of these colonised subjects. Moreover, contra Frank, the subversive acts are testimony to why the colonies were never able to be 'fully' colonised, or why colonisation was never completely 'effective'. Contra Cardoso and Faletto, these acts show that Third World politics does not have to wait to happen until the end of 'formal' colonialism (see James, 1997: 219).

A further assumption is that agency is only possible from within the confines of the nation-state. For Kate Manzo this is indicative of dependency's entrapment 'within a modernist discourse which relies on the principles of nineteenth-century liberal philosophy, [and] which treats the individual nation-state in the Third World as the sovereign subject of development' (1991: 6). In this connection, Bhabha, in the only direct critique he makes of dependency, avers that:

The postcolonial perspective departs from the traditions of the sociology of underdevelopment or the 'dependency' theory. As a mode of analysis, it attempts to revise those nationalist or 'nativist' pedagogies that set up the relation of the Third and First Worlds in a binary structure of opposition. The postcolonial perspective resists attempts to provide a holistic social explanation, forcing a recognition of the more complex cultural and political boundaries that exist on the cups of these often opposed political spheres ... It is from this hybrid location of cultural value-the transnational as the translational-that the postcolonial intellectual attempts to elaborate a historical and literary project. (1995a: 49)

On the one hand, Bhabha is critical of the equation of the political subject with the nation-state. As already noted, he, like Spivak, shifts focus away from the 'grand' politics of state and class to the everyday and 'marginal' acts of the subaltern. On the other hand, he is also suspicious of the very idea of the 'nation', at least to the extent that it refers to a unitary and undivided subject. He argues instead for the replacement of the presumed homogeneous and 'pure' or 'authentic' national identity with a liminal, split and ambivalent identity, and of the 'horizontal, homogenous empty time of the nation's narrative' with the 'double' and 'disjunctive temporality' of the people (1994: 145-149). Of particular interest to him are how national cultures are 'being produced from the perspective of disenfranchised minorities' (1994: 6), not only in the Third World but also in the West (ie by migrants, refugees, or diasporas hailing from the excolonies). For, once again, this production shows up for him the artificial and differentiated character of the nation-state, while also complicating the 'cultural and political boundaries' between periphery and metropole.

To conclude this section, a brief summary of the postcolonial critique of dependency just staged. While not denying that both camps have notable common concerns, and while even suggesting some partial convergences between Frank and Said, as well as between Cardoso and Faletto and Spivak and Bhabha, I have attempted to bring out the main vulnerabilities of dependency from the vantage point of postcolonialism. Postcolonial theory argues that dependency's counter-modernist and critical inclinations are not, ironically, counter-modernist and critical enough, principally because dependency does not 
shed its modernist past. As Manzo suggests, 'even the most radically critical discourse easily slips into the form, the logic, and the implicit postulations of precisely what it seeks to contest, for it can never step completely outside of a heritage from which it must borrow its tools-its history, its language-in its attempt to destroy that heritage itself' (1991: 8). Thus, dependency is unaware of its orientalism; despite itself, it ends up incorporating the non-Western world into a eurocentric and teleological historiography, ignoring or flattening difference, and denying agency to the Third World. When it does bestow agency, the agent is identified with the nation-state. But here again dependency overlooks how its nationalist and statist proclivities can dismiss or suppress heterogeneity and subalternity.

\section{A dependentista critique of postcolonial theory}

To turn now to the blind spots and weaknesses of postcolonial theory, as teased out by dependency. This critique will be carried out on the basis of two considerations: the status of capitalism in postcolonial theory; and the breadth of postcolonial historiography and politics.

\section{The status of capitalism}

From the perspective of dependency, postcolonial theory does not adequately appreciate the role of capitalism, resulting in significant political problems. This critique applies somewhat differently to Said and Bhabha than to Spivak. Said and Bhabha assign capitalism no significant place in their respective analyses. The very titles of some of their works (eg Culture and Imperialism, The Location of Culture ) reveal their bias towards cultural, as opposed to economic, arguments. Said's writing, as indicated earlier, repeatedly underlines his interest in discourse and the politics of representation. Bhabha makes occasional references to 'multinational capital' and the 'multinational division of labour' (1994: 241, 6), but nonetheless errs on the side of semiotics and discursivity. This is evident in such formulations as: "popular rebellion and mobilization are often most subversive and transgressive when they are created through oppositional cultural practices' (1994: 20, emphasis added; see also Parry, 1996: 8-9; 1987).

The problem is that questions of economic inequality, so central to dependency, tend to be given short shrift by this semiotic approach to politics. It is as though interactions or 'negotiations' among and between coloniser and colonise d are barely affected by their differential socioeconomic status. As Moore-Gilbert points out, Bhabha 'assumes that the effective economies of mimicry and ambivalence operate equivalently for all colonial subjects irrespective of their positioning in the social hierarchy' (1997: 168; see also 110; Ahmad, 1997: 370; O'Hanlon \& Washbrook, 1992). Does the colonised subject's status in the capitalist economy not impinge on her/his ability to represent or negotiate, or on how forcefully s/he can represent or negotiate in relation to another subject? Bhabha appears to provide no answers. As above, he asserts that oppositional cultural practices are 'often most subversive and transgressive' (presumably, relative to 'material' ones), but offers no comparative political economy analysis 
to support this claim.

In this regard, it is significant that Bhabha, or for that matter Said or Spivak, does not focus on capitalist transactions or economically orientated subversive agency by the subaltern or migrant (eg non-payment of colonial taxes, revolts against landlords, action against inhuman working conditions, etc). In keeping with his post-structuralist politics of representation, he prioritises agency in the 'post-materialist', symbolic sphere-the estrangement of Christianity or the subversion of Western orientalism and colonial stereotypes. As a consequence, several critics accuse postcolonial theorists like him of ignoring such key 'material' issues as distribution or poverty in their politics (Sylvester, 1999: 703; Pieterse \& Parekh, 1995: 13; Sunder Rajan, 1997: 615). They point out as well that, contrary to the implication that social struggles are primarily over 'symbolisation', many of today's social movements are struggles 'for' development (ie for better access to health, environment, jobs, etc) (Storey, 2000: 42). The postcolonial anti-economic bias, then, is out of kilter with the significant and continuing 'materialist'-orientated forms of subaltern agency in the Third World.

While Spivak may be said, for the most part, also to display some of the abovementioned weaknesses, it must be noted that she does pay significant attention to the role of capital. She draws on class analysis, and often quotes the work of Marx, Gramsci and Althusser. But the problem for the dependentistas, as for Marxist analysts generally, is not that capitalism is merely acknowledged as playing a role; it is, rather, the relative importance given to this role. For them, capital is foundational or ontological. This is attested to by Frank's argument (underlined earlier) about a single world capitalist system, a position supported by Cardoso and Faletto: 'without the concept of capital ... it is not possible to explain the movement of capitalist society ... history becomes understandable when interpretations propose categories strong enough to render clear the fundamental relations that sustain and those that oppose a given structural situation in its globality' (1979: xiii). In contrast, postcolonial theory approaches capitalism epistemologically. Aijaz Ahmad characterises this as the 'literary-critical habit of seeing all history as a contest between different kinds of narrative, so that imperialism itself gets described not in relation to the universalisation of the capitalist mode as such but in terms of the narrative of this mode' (1997: 376, emphasis in the original). As a consequence, as Ahmad goes on to explain, postcolonial critics treat Marxism 'as a method primarily of reading ... [thus reducing it] to an element among other elements in the analytics of textual reading'. It is not Marxism per se, then, but 'reading [that becomes] the appropriate form of politics' (Ahmad, 1992: 4-5, 3, emphasis in the original; see also 70; Dirlik, 1994: 335; O'Hanlon \& Washbrook, 1992). The trap, as Hall submits, is assuming that, because a narrative has been read and deconstructed epistemologically and theoretically, 'therefore it has been displaced politically' (1996: 249, emphasis in the original).

For the most part, Spivak appears to confirm Ahmad's above-mentioned characterisation, although it must be noted that she does equivocate. Her writings contain references to the 'real' as independent of representations or sign-systems, so that the international division of labour is portrayed as responsible for subjectconstitution (Moore-Gilbert, 1997: 100-103). An example of this tendency is the 
following statement: 'Woman's body is thus the last instance in a system whose general regulator is still the loan: usurer's capital, imbricated, level by level, in national industrial and transnational global capital' (1993: 82; see also 1999: 315). But more often than not, she speaks of 'facts' as 'discursively constructed' (1988a: 242) and of the mode of production as a 'narrative' (eg 1985a: 258; 1990a: 101, 162).

This epistemological approach to capitalism should come as no surprise, given postcolonial theory's anti-essentialist leanings. As the postcolonial historiographer Gyan Prakash reminds us, the idea is not to make capitalism a 'disposable fiction' but rather to warn that 'making capitalism the foundational theme amounts to homogenizing the histories that remain heterogenous within it' (1992b: 176). Yet this position has several questionable consequences. That there are no ultimate foundations may be an important and valid stand, but it evades the important point that some explanations or narratives are better or more convincing than others. In her attempt to valorise incommensurability and heterogeneity, Spivak provides no way of sifting through different epistemologies or, to use Cardoso and Faletto's above-quoted words, no 'strong enough' categories to decide which representations are more important. For example, given the current intensification of capitalist globalisation and spread of multinational corporations, Spivak supplies no clues about how either to recognise the magnitude of the problem or to prioritise effective political responses. And she has no way of adjudicating between, say, the claims and narratives of anti-immigrant neofascists and new immigrants or refugees. ${ }^{11}$ Whose claims are more compelling, and how are we to assess or rank them? Her (and her postcolonial colleagues') refusal to erase, check or adjudicate difference runs into notable political conundrums in these not uncommon types of situations.

\section{The breadth of history and politics}

Postcolonial theory, as argued earlier by Bhabha, resists 'holistic social explanations' and focuses instead on heterogeneity and ambivalence. In the place of chronological or dialectical history, for example, it offers discontinuous historical narratives. In particular, Bhabha and Spivak (but not Said) concentrate on isolated historical incidents and agents, refraining from providing any 'meta' historiography. This is a problem from where dependency sits, for history then becomes merely a collection of fragmentary narratives. In this connection, Ahmad writes that the 'work of Bhabha is particularly telling of the way this kind of hermeneutic tends to appropriate the whole world as its raw material and yet effaces the issue of historically sedimented differences. Indeed the very structure of historical time is effaced in the empty play of infinite heterogeneities' (1997: 370; see also Parry, 1996: 11). The advantage of dependency's structuralhistorical perspective is that it enables the recognition of broad patterns and trends, which in turn allows one to relate the present to the past, or learn from past mistakes to change the future. Postcolonial theory's 'sedimented' historiography makes many of these tasks difficult, if not impossible.

A similar problem arises with postcolonial agency and politics. The emphasis on local discourses and action tends to result in the neglect of broader influences 
and impacts (Joss, 1996: 245; see also Dirlik, 1994: 345; Hall, 1997). Global concerns may be central to the postcolonial analysis of cultural hegemony and orientalism, but it remains unclear how postcolonial interventions impinge, in turn, on global power. In fact, it is difficult to imagine how the micro-political scale of postcolonial agency, as well as the micro-size of its agents, can meaningfully affect macro-politics. The postcolonial suspicion and deconstruction of the nation-state does not help here either. Although not without its limitations, the state may sometimes have to take on an increasingly important role. As the dependentistas insist, the proliferation of multinational capital makes the establishment of a semi-autonomous state a must if dependency and imperialistic ties are to be minimised. In contrast, the sub-national and decentred character of postcolonial agency risks allowing corporate power to overshadow it, and may even end up aiding, not regulating or altering, corporate propagation.

To conclude this section, I would like to draw attention to the way in which the dependentista critique brings out the limitations of the types of questions being asked by postcolonial theory. Postcolonialism's emphasis on cultural and representational issues leads it to ignore important material concerns (eg poverty, health, etc). To the extent that it does consider materialist and capitalist problems, it approaches them epistemologically, shying away from the important political task of prioritising or adjudicating among differing narratives (be they economic, cultural, social, environmental). Finally, although it examines global-local questions, these tend to be one-sided: they illuminate well how global power is reproduced in the local, but when it comes to politics, they reveal only local agency, not global consequences.

\section{Conclusion}

While both sides in the above-staged debate are critical of Western liberal modernity, their critiques are different, with the result that each one accuses the other of being insufficiently critical. Dependency points to postcolonial theory's narrow analysis and politics, and its inadequate consideration of the socioeconomic inequality and unevenness engendered by capitalist modernity. Postcolonial theory reproaches dependency for its lack of self-reflexivity, and hence for adopting a modernist framework that is totalising, ethnocentric and prone to erasing sociocultural and political difference(s). This mutual critique helps reveal the strengths and limits of both sides. Often, what one party sees as significant, the other construes as problematic. The debate, as a consequence, teases out important tensions between several of the ingredients of Third World politics: materialism and culture, state and subaltern, centralised and decentralised agency, local, national and global interventions, totality and specificity or heterogeneity, teleological historiography and discontinuous historical narratives, structuration and hybridity, transcendence and incommensurability, dualism and ambiguity.

The staged debate also helps shed new light on dependency. While many may consider dependency old-fashioned today, brought into conversation with postcolonial theory, it regains relevance and contemporaneity. Although much more work and thought are required, its insights into the historical and global workings 
and impacts of capitalism in the Third World appear highly pertinent to current research on globalisation. It can also be seen as acting as a materialist counterbalance to postcolonial-inspired discursive and representational analysis currently popular in the study of Third World and global issues. Finally, its statist and 'holistic' perspective, while not without reproach, is a cautionary note to postcolonial theory's decentred and, so-to-speak, 'globalisation from below' approach.

\section{Notes}

Thanks to Kent Murnaghan, as always.

I I do not purport to represent the gamut of arguments and positions of these Marxist critics of postcolonial theory, only those arguments relating to important dependency themes (eg the role of history, the status of capitalism, etc). I do not endorse, for example, the (implicit or explicit) argument by some of these critics that postcolonial theorists such as Said, Spivak or Bhabha are nothing but Western-based academic apologists for the current ascendancy of global capitalism (Dirlik, 1994: 329, 356; Ahmad, 1992: 6; Miyoshi, 1993: 728). Not only are such arguments reductionist (the postcolonial theorists are highly critical of Western modernity; and Spivak, for instance, explicitly and repeatedly addresses her location as a 'privileged' intellectual in the academy, which is more than one can say for Dirlik, Ahmad or Miyoshi), but they are also anti-intellectual in suggesting that one's intellectual activity is straightforwardly determined by one's socioeconomic or geographic location. (On this issue, see Hall, 1996: 258-259; Gandhi, 1998; Sylvester, 1999: 715). Moreover, it should be noted that not all dependency theorists are 'Marxist', although the vast majority of their work is Marxist inspired. Similarly, not all dependency theorists are Marxist in the same way (as will be seen later in this article). Frank is often labelled a 'neomarxist', inspired by Paul Baran's idea of the 'development of underdevelopment'. He does not make use of classical Marxist 'modes or production' analysis, and he tends to see the national bourgeoisie as a puppet of imperialism. Cardoso and Faletto, although Marxist inspired, tend to draw from non-Marxist sources as well, in particular from the idea of a possible progressive role being played by non-class groups and ideologies (ie urban groups, the military, populism, nationalism, etc). They are thus neither 'neomarxists' nor 'classical Marxists'. They believe in examining the structural relations between imperialism and social classes and groups, and see a possible (but not necessarily) progressive role being played by the national bourgeoisie (which is a 'classical Marxist' argument). (See Blomström \& Hettne, 1994: 34-35, 61-63, 89; Foster-Carter, 1973).

2 I will distinguish between 'post-colonial' and 'postcolonial' (ie no hyphen), the former adjective being used to denote the period after Third World countries obtained political independence, the latter to denote the critical literary field.

3 The notion of the 'internalisation of imperialism' is one that features prominently in the work of socalled 'postdependency' theorists such as Peter Evans (1979).

4 See also the 'Afterword' to the 1995 edition of Orientalism (first edition 1978) (1995: 348-349, 352).

s However, it should be noted that in Orientalism Said does recognise the agency of individual authors, believing them not always to be an 'effect' if discourse. Here, he is forging a more 'humanist' approach than Foucault, whom he takes to task over this issue (1995: 23-24, 27).

- Bhabha draws on the Lacanian argument that we are inherently linguistic beings, and that, because language is an unstable and arbitrary string of differentiated signs, any attempt at closure or homogeneity (eg a fixed or monolithic discourse, a racist or orientalist stereotype) is doomed to failure and/or instability (see Bhabha, 1994: 124-125, 191; 1995a: 51).

7 Other examples of subversive agency include (not an exhaustive list): (1) 'Sly Civility' (1994: 93ff), where the native defers ('civility') to and yet differs ('sly') from the coloniser's demand for rationality; (2) 'Of Mimicry and Man' (1994: 85ff.), where the colonisers' civilising mission to produce 'mimic men' is resisted, because mimicry can easily slide into menace and mockery; and (3) 'By Bread Alone' (1994: 198ff), where a British stereotypical rumour about Indian villagers passing a chapati (flat bread) from hand-to-hand and village-to-village before the 'Indian Mutiny' ends up being disarming: 'The iterative action of rumour, its circulation and contagion, links it with panic-as one of the affects of insurgency' (1994: 200, emphasis in the original).

8 Presumably Bhabha uses 'spectacular' not only to validate this subaltern act of resistance, but also to draw attention to its character as 'spectacle'.

9 Bhabha, in particular, is critical of this kind of view of culture (which he calls 'cultural diversity'), 
where 'culture is made an object of empirical knowledge' and hence tends towards orientalist and fixed notions of tradition or custom. Instead, he points towards 'cultural difference', which is more about examining the 'enunciation of culture', its hybrid location, its production from the margins (1994: 34).

${ }_{10}$ In many ways, the Laclau-Frank debate further brings out the totalising character of Frank's view of power. Laclau (1986) argues that Frank's view of capitalism does not adequately consider the 'mode of production'. This causes Frank to identify Latin America incorrectly as having only one mode (a capitalist one), and to assert that it has never even been 'feudal' (Frank, 1967: 115). For Laclau, this argument misses the point that any given economic system can have mixed or coexisting modes of production, although he agrees with Frank that these modes are non-dual and intimately linked. The upshot, as Randall and Theobold point out, is that 'Laclau finds himself, paradoxically, in agreement with Frank that development does indeed generate underdevelopment, except that Laclau is arguing that exploitation is between two modes of production rather than within one capitalist mode of production' (1985: 134). However, in the 'Indian mode of production debate', Banaji and Alavi counter Laclau, and side more (although not entirely) with Frank. They argue that Laclau cannot have it both ways: a feudal mode cannot both coexist with a capitalist mode and be linked to it: either the two modes would coexist and hence be in contradiction with one another, or the feudal mode would be in the service of imperialism, which is what Frank argues in the first place (Blomström \& Hettne, 1994: 129-130; Alavi, 1975).

"Sometimes, Spivak attributes these gaps to her being a 'bricoleur' and using 'what comes to hand' (1988b: 281; 1990a: 55), as though issues of adjudication and political and epistemological prioritisation can be left to whim or chance.

\section{References}

Ahmad, A (1992) In Theory (London: Verso).

Ahmad, A (1997) Postcolonial theory and the 'post-' condition, Socialist Register 1997 (London: Merlin Press), pp 353-381.

Alavi, H (1975) India and the colonial mode of production, Socialist Register 1975 (London: Merlin Press), pp 160-185.

Bhabha, HK (1994) The Location of Culture (New York: Routledge).

Bhabha, HK (1995a) Freedom's basis in the indeterminate; and Discussion, in: J Rajchman (ed), The Identity in Question, pp 47-61, 85-90 (New York: Routledge).

Bhabha, HK (1995b) Translator translated, interview with WJT Mitchell, Arfforum, March, pp 80-83, $110,114,118-119$.

Blomström, M \& Hettne, B (1984) Development Theory in Transition, The Dependency Debate and Beyond (London: Zed).

Cardoso, FH (1972) Dependent capitalist development in Latin America, New Left Review, 74, pp 83-95.

Cardoso, FH (1973) Associated-dependent development: theoretical and practical implications, in: A Stepan (ed), Authoritarian Brazil: Origins, Policies, and Future, pp 142-176 (New Haven, CT: Yale University Press).

Cardoso, FH \& Faletto, E (1979) Dependency and Development in Latin America (Berkeley, CA: University of California Press).

Chakrabarty, D (1992) Postcoloniality and the artifice of history: who speaks for 'Indian' pasts?, Representations, 37, pp 1-26.

Dirlik, A (1994) The postcolonial aura: Third World criticism in the age of global capitalism, Critical Inquiry, 22, pp 328-356.

Evans, P (1979) Dependent Development: The Alliance of Multinational, State, and Local Capital in Brazil (Princeton, NJ: Princeton University Press).

Fanon, F (1967) Black Skin, White Masks (New York: Grove Press).

Foster-Carter, A (1973) Neomarxist approaches to development and underdevelopment, Journal of Contemporary Asia, 3 (1), pp 7-33.

Frank, AG (1967) Capitalism and Underdevelopment in Latin America (New York: Monthly Review Press).

Frank, AG (1969) Latin America: Underdevelopment or Revolution (New York: Monthly Review Press).

Frank, AG (1972) Lumpenbourgeoisie-Lumpendevelopment (New York: Monthly Review Press).

Frank AG (1977) Dependence is dead, long live dependence and class struggle: an answer to critics, World Development, 5 (4), pp 355-370.

Frank, AG \& Gills, BK (eds) (1993) The World System: Five Hundred Years or Five Thousand? (New York: Routledge).

Frank, AG (1998) ReOrient (Berkeley, CA: University of California Press). 
Furtado, C (1970) Economic Development of Latin America (Cambridge: Cambridge University Press).

Gandhi, L (1998) Postcolonial Theory: A Critical Introduction (St Leonards: Allen and Unwin).

Hall, S (1996) When was 'the post-colonial'? Thinking at the limit, in: I Chambers \& L Curti (eds), The Post-Colonial Question, pp 242-260 (London: Routledge).

Hall, S (1997) The local and the global: globalization and ethnicity, in: AD King (ed), Culture, Globalization and the World-System, pp 19-39 (Minneapolis, MN: University of Minnesota Press).

James, P (1997) Postdependency? The Third World in an era of globalism and late-capitalism, Alternatives, 22, pp 205-226.

Joss, J (1996) Postcolonialism: subverting whose empire?, Third World Quarterly, 17 (2), pp 239-250.

Laclau, E (1986) Feudalism and capitalism in Latin America, in: PF Klaren \& TJ Bossert (eds), Promise of Development (Boulder, CO: Westview).

Manzo, K (1991) Modernist discourse and the crisis of development theory, Studies in Comparative International Development, 26 (2), pp 3-36.

Miyoshi, M (1993) A borderless world? From colonialism to transnationalism and the decline of the nation-state, Critical Inquiry, 19, pp 726-751.

Moore-Gilbert, B (1997) Postcolonial Theory (London: Verso).

O'Hanlon, R \& Washbrook, D (1992) After orientalism: culture, criticism, and politics in the Third World, Comparative Studies in Society and History, 34, pp 141-167.

Parry, B (1987) Problems in current theories of colonial discourse, Oxford Literary Review, 9, pp 27-58.

Parry, B (1996) Sign of our times, Third Text, 28 (9), pp 5-24.

Pieterse, JN \& Parekh, B (eds) (1995) The Decolonization of the Imagination: Culture, Knowledge and Power (London: Zed).

Prakash, G (1990) Writing post-orientalist histories of the Third World: perspectives from Indian historiography, Comparative Studies in Society and History, 32 (2), pp 383-408.

Prakash, G (1992) Postcolonial criticism and Indian historiography, Social Text, 31/32, pp 8-19.

Randall, V \& Theobold, R (1985) Political Change and Underdevelopment (London: Macmillan).

Said, E (1985) Orientalism reconsidered, in: F Barker et al (eds), Europe And Its Others, Vol 1, pp 14-27 (Colchester: University of Essex).

Said, E (1993) Culture and Imperialism (New York: Vintage).

Said, E (1995) Orientalism (London: Penguin).

Spivak, GC (1985a) The Rani of Sirmur: an essay in the reading of archives, History and Theory, 24 (3), pp 247-272.

Spivak, GC (1985b) Strategies of vigilance: an interview with Gayatri Chakravorty Spivak, Block, 10, pp 5-9.

Spivak, GC (1988a) In Other Worlds (New York: Routledge).

Spivak, GC (1988b) Can the subaltern speak?, in: C Nelson \& L Grossberg (eds), Marxism and Interpretation of Culture, pp 271-313 (Chicago, IL: University of Illinois Press).

Spivak, GC (1990a) The Post-Colonial Critic, ed S Harasym (New York: Routledge).

Spivak, GC (1990b) Poststructuralism, marginality, postcoloniality and value, in: P Collier \& H GreyerRyan (eds), Literary Theory Today, pp 219-244 (London: Polity Press).

Spivak, GC (1993) Outside In The Teaching Machine (New York: Routledge).

Spivak, GC (1996) The Spivak Reader, ed D Landry \& G MacLean (New York: Routledge).

Spivak, GC (1999) A Critique of Postcolonial Reason (Cambridge, MA: Harvard University Press).

Storey, A (2000) Romanticism and Pontius Pilate politics, Development, 43 (4), pp 40-46.

Sunder Rajan, R (1997) The Third World academic in other places; or the postcolonial intellectual revisited, Critical Inquiry, 23 (3), pp 610-618.

Sylvester, C (1999) Development studies and postcolonial studies: disparate tales of the 'Third World', Third World Quarterly, 20 (4), pp 703-721.

Werbner, R \& Ranger, T (eds) (1996) Postcolonial Identities in Africa (London: Zed).

Young, R (1990) White Mythologies: Writing History and the West (London: Routledge). 